\title{
The Welfare Capitalism of John Morrell and Company, 1922-1937
}

\section{WILSON J. WARREN}

John Morrell and Company, one of the United States' leading independent meatpackers during much of the twentieth century, like many industrial giants, experimented with "welfare capitalism" in the 1920s and 1930s. Although Morrell designed its plan to foster more harmonious labor-management relations, its welfare programs did not meet the expectations or needs of workers at its Ottumwa, Iowa plant. The workers, especially those in the beef-kill and hog-kill departments, agitated instead for their own union to satisfy their desire for a more equitable work situation. Consequently, Morrell's attempt to create an industrial "family" between 1922 and 1937 came to an end when employees elected Local \#32 of the Packinghouse Workers' Organizing Committee as their bargaining agent on October 28, 1937. Morrell's example, then, may help identify the inherent weaknesses that caused welfare capitalism's failure to fend off the blows of rising unionization in the 1930s. ${ }^{1}$

1. Ellis Hawley, Shelton Stromquist, Merle Davis, Wayne DeJohn, and Timothy Cary gave the author their constructive criticisms of this article. The author based many findings on the interviews which are a part of the lowa Labor History Oral Project (ILHOP), sponsored by the lowa Federation of Labor, AFL-CIO. The project's subjects are peóple who participated in the development of Iowa's labor history since the early twentieth century. Presently the project is closed to the public (except by special permission) until its completion. It is housed in the library of the lowa State Historical Department in Iowa City. Unless otherwise indicated, all interviews here cited occurred in Ottumwa, Iowa. The author also conducted additional interviews when possible. Particularly helpful were: Virgil Bankson, interview with author, 26 September 1982 and Virgil Bankson, interview with Iowa Labor History Oral Project, 1978. Virgil Bankson started work at Morrell in Ottumwa in 1924. In the early 1930s, he began in the beef-kill 
Welfare capitalism, one facet of the "American Plan" during the New Era, was "any service provided for the comfort or improvement of employees which was neither a necessity of the industry nor required by law."'2 By a more skeptical definition, it was a movement to maintain the open shop through reform from within an industry. At John Morrell and Company in Ottumwa, it primarily included programs in three areas: employee representation in a company union; establishment of personnel and employment departments that left the power of foremen and superintendents largely intact; and provision for a variety of employee benefit programs. Morrell introduced most of these employee welfare plans from 1922 to 1925, after its victory over a local of the Amalgamated Meat Cutters and Butcher Workmen of North America (American Federation of Labor) in a 1921 strike. Although comprehensive reform measures were not common in Iowa, managers at Morrell hoped that these programs-most specifically, the company unionwould establish "industrial democracy" between management and labor and keep out industrial unions. ${ }^{3}$ Management hoped to inspire workers' identification with their employing company and to make them receptive to the efficiency and productivity of the new scientific management. Indeed, welfare capitalism was part of a larger "reform from above" effort aimed at reducing worker resistance to managerial goals. Ultimately, of course, industrial unions would largely replace company ones, because company unions were unsatisfactory and because the federal government forbade them in the National Labor Relations, or Wagner, Act of 1935.

Historians have debated welfare capitalism's ability to control and placate industrial work forces. Traditionally they have disparaged welfare programs. In the 1920s, for example,

department. After working in this department, he and his brother Art Bankson, who started at the plant in 1933, began promoting labor union activity. Virgil later became one of the leaders of the United Packinghouse Workers of America (UPWA) local in Ottumwa and served as its chief steward for eighteen years, intermittently from the mid-1940s to 1973.

2. Stuart D. Brandes, American Welfare Capitalism, 1880-1940 (Chicago, 1976), 5.

3. Lawrence Oakley Cheever, The House of Morrell (Cedar Rapids, 1948), 194-197; David Yoder, Labor Attitudes in Iowa and Contiguous Territory, vol. 5, Iowa Studies in Business (lowa City, 1929), 82. 
Herbert Feis and Robert Dunn demonstrated the limitations of company unions. In 1960, Irving Bernstein noted that instances of effective dialogue between labor and management were few and that welfare programs invariably left workers without effective grievance machinery. In the 1970s, Stuart D. Brandes wrote that employers saw welfare capitalism as a "defensive strategy [and] protective device aimed largely at trade unionism." Robert $\mathrm{H}$. Zeiger asserted that management's views on employee representation placed inherent limits on its ability to meet worker needs. Even where employee representation plans successfully undermined trade unionism, they "provided far more propaganda and good will value to employers than they did democratic representation to workers." Recently, however, David Brody claimed that welfare capitalism might have succeeded had the wage cuts of the Depression not occurred. Mansel G. Blackford, Gerald Zahavi, and Daniel Nelson have argued that welfare capitalism did work in particular plants and companies. Nelson has pointed out that distinctions between varieties of welfare capitalism and company unions make generalizations about their inadequacies questionable. $^{4}$

A crucial part of this debate has to do with the rising influence of personnel departments. Traditionally, historians have seen these instruments of managerial reform as reducing the power and arbitrary rule of foremen while enhancing the centralized control of plant managers. Irving Bernstein and James Green have accepted this interpretation. Daniel Nelson

4. Herbert Feis, Labor Relations: A Study Made in the Proctor and Gamble Company (New York, 1928), 69-70; Robert W. Dunn, Company Unions: Employers' 'Industrial Democracy' (New York, 1927); Irving Bernstein, The Lean Years: A History of the American Worker, 1920-1933 (Boston, 1960), 73; Brandes, American Welfare Capitalism, 32; Robert H. Zeiger, "Herbert Hoover, the Wage-earner, and the 'New Economic System,' 1919-1929," Business History Review 51 (Summer 1977), 181-187; David Brody, "The Rise and Decline of Welfare Capitalism," in David Brody, ed., Workers in Industrial America: Essays on the Twentieth Century Struggle (New York, 1980), 48-81; Mansel G. Blackford, "Scientific Management and Welfare Work in Early Twentieth Century American Business: The Buckeye Steel Castings Company," Ohio History 90 (Summer 1981), 238-261; Gerald Zahavi, "Negotiated Loyalty: Welfare Capitalism and the Shoeworkers of Endicott Johnson, 1920-1940," Journal of American History 70 (December 1983), 602-620; Daniel Nelson, "The Company Union Movement, 1900-1937: A Reexamination," Business History Review 56 (Autumn 1982), 335-357. 
and Sanford Jacoby, however, believe that personnel departments did not always spell the end of the foremen system. Where they did not, and the foremen maintained some hold, new welfare programs and employee representation plans were even less liable to create industrial harmony. ${ }^{5}$ The case of Morrell in Ottumwa supports those who have stressed welfare capitalism's failure to create a stable system of industrial relations. Morrell's example also suggests that "industrial democracy" was unattainable when the foremen still held significant power. Morrell's welfare capitalism was a reform facade that did little to improve the plant's labor relations.

JoHN MORRELL and Company had begun its meatpacking operations in Bradford, England in 1827 and moved its headquarters to Liverpool in 1860 . The company then opened branch plants in London (Ontario) and Chicago. In the .1870 s the search began for a location closer to the hog-farming regions which supplied the plants, and in 1877 Thomas Dove Foster (a grandson of the founder, George Morrell) established a plant at Ottumwa, Iowa. It quickly became the largest industry and employer in the Ottumwa area. In 1888, the plant became the general headquarters of the Company's American branch and, despite a fire which in 1893 almost closed the plant, Morrell prospered and continued to dominate the town's economy. ${ }^{6}$

Before 1900, under T.D. Foster's leadership, the company introduced at least three types of welfare measures in its Ottumwa plant: the Mutual Aid Association, company picnics, and Young Men's Christian Association (YMCA) work. Two butchers and a laborer originally conceived the Mutual Aid Association, a plan to aid injured or sick workers by collecting a small weekly fee from those workers who wished to participate. Approved in 1893, it provided benefits primarily to the

5. Bernstein, Lean Years, 177; James R. Green, The World of the Worker: Labor in Twentieth Century America (New York, 1980), 102-110; Nelson, "Company Union Movement," 343-345; Sanford Jacoby, "The Rise of Internal Labor Markets in American Manufacturing Firms, 1910-1940" (Ph.D. diss., University of California, Berkeley, 1981), 504-511.

6. Cheever, House of Morrell, 1-88; R. Ames Montgomery, Thomas D. Foster (Cedar Rapids, 1930), 95; Neil M. Clark, "What Size Business is Best?" Forbes, 1 June 1935, 9. 
more skilled (and thus more regularly employed) workers. Management introduced the picnics in the $1880 \mathrm{~s}$ and promoted them to instill a spirit of unity between management and labor. Thomas Dove Foster was also a great proponent of the YMCA movement. He served as president of the Ottumwa association, promoted it statewide, and introduced community and industrial lecture programs in part directed at company workers who had rooms at the East End YMCA adjacent to the Morrell plant. Like many other businessmen in the movement, he was "deeply religious" and committed to "Christianizing" the laboring classes and inculcating in them good will toward capitalism and the status quo.?

During the same pre-World War I period, union organizing had not reached the Ottumwa plant. From 1901 to 1904, when the Amalgamated Meat Cutters and Butcher Workmen of North America were successfully organizing the Chicago packing plants, the Ottumwa plant workers remained unorganized and did not participate in the nationwide meatpackers' strike of 1904. The Amalgamated local in the Ottumwa plant consisted of only a few skilled butchers (about thirty men in a plant which employed over a thousand), whose residential, home-ownership, and income patterns set them apart from (and above) the rest of the work force, and whose moral code and sense of craftsmanship left them largely unconcerned about the plight of fellow workers. Unlike the labor groups in Chicago, they made no effort to bring the unskilled into the Amalgamated. While their local persisted, it remained under the domination of skilled workers who were largely unresponsive to calls for a union of all plant workers. The war period, however, with its governmental guarantees of the right to organize, did lead to Amalgamated membership for a significant portion of the Morrell workers. Morrell maintained an open shop, but it did, under government pressure, guarantee a forty-hour work week and a minimum wage of forty cents an hour for unskilled labor. The plant's workers tried to preserve these gains in the postwar period, and conflict over them produced the strike of October 19 through December

7. Wilson J. Warren, "Workers and Labor Organizing at Morrell: A Quantitative Study of the Packing House Community of Ottumwa, lowa, 1880-1915" (unpublished MS, Ottumwa Public Library), 30-32; Jacoby, "Rise of Internal Labor Markets," 147-152. 
24, 1921. This strike in turn precipitated the introduction of welfare capitalism. ${ }^{8}$

John Jordan, who first worked at the plant in 1917 and early became a union member, said the company had been trying to break the union for at least a year before the strike. Morrell hired Pinkerton detectives to infiltrate the union. By August 1921, the company had decided that it could no longer maintain wartime hour and wage guarantees. It proposed to replace them with a thirty-two hour guaranteed work week and freedom to hire unskilled labor at wages below forty cents, which the union found unacceptable. Four months later, employees of the beef-kill and hog-kill departments led a general walkout which effectively stopped the plant's operation. ${ }^{9}$

The workers initially called the walkout to support aggrieved women who did meat trimming. The women had been paid on a piece-work basis, but when their contract expired the company decided to establish a day-rate basis of pay. The women walked out to protest this change and, soon after, men in the kill and cut departments joined to support them and to secure a return to the forty-hour guaranteed work week and the forty-cent minimum wage. Worker delegates then attempted to meet with plant superintendent Ernest Manns. When Manns abruptly dismissed them, the union decided to strike for both the former hour and wage guarantees and the right to continue collective bargaining through the Amalgamated. ${ }^{10}$

8. Although the general issues were similar, this strike was not officially part of the nationwide Amalgamated strike that lasted from December 5, 1921 to February 1, 1922. See David Brody, The Butcher Workmen: A Study of Unionization (Cambridge, 1964) and Alfred "Pat" Crow, interview with ILHOP, 1978. Crow started working for Morrell in Ottumwa at the age of thirteen. He worked in the kill and cut departments through the 1930s. For background on Amalgamated see Warren, "Workers and Labor Organizing," 27-30, and James R. Barrett, "Work and Community in 'The Jungle": Chicago's Packing House Workers, 1894-1922" (Ph.D. diss., University of Pittsburgh, 1981), 420-423, 121-141.

9. John Jordan, interview with ILHOP, Ankeny, Iowa, 7 April 1978. Jordan grew up in the packinghouse community of Ottumwa and his father managed a restaurant across the street from the plant. Jordan worked at Morrell for only a short time before moving away from Ottumwa.

10. Ottumwa Daily Courier, 19 October 1921, 20 October 1921; Des Moines Register, 20 October 1921; John Jordan, interview; Paul Bissell, interview with author, 10 January 1983. 
After an announcement by T.D. Foster's son, Vice-President Thomas Henry Foster, on October 22 that Morrell would only rehire union members as individuals, the company steadily resumed hog and beef killing. Morrell used scabs to replace the regular work force and from late October to mid-November the strikers did not prevent them from entering the plant. Alfred Crow and others recalled the company's strikebreaking and scab-recruiting efforts, including the importation of blacks. ${ }^{11}$ The strikers' frustration at being unable to block the scabs and strikebreakers led, on the morning of November 15, to a street brawl. The fight, which involved two hundred to three hundred people, broke out after more scabs had attempted to enter the plant. During the struggle strikers forcibly stopped Ernest Manns's car at a nearby railroad crossing and hit T.H. Foster in the head with a rock thrown through his car window. In all there were some twenty-five injuries.

A committee of Ottumwa citizens claimed that the city police had been unable to control the situation. T. H. Foster, Ottumwa Mayor Charles Chilton, and Wapello County Sheriff George Giltner headed the committee which urged Iowa Governor Nathan Kendall to help restore order. The governor proved responsive. On November 16, he sent four companies (about 250 troops) of the Iowa National Guard to Ottumwa, the first use of national guard troops in Iowa since the Muscatine button strike of 1911. The Wapello County Attorney deputized 150 local men as well and this police presence quelled disturbances at the plant. ${ }^{12}$

Partly due to the urging of John C. "Shady" Lewis, president of the lowa State Federation of Labor, Governor Kendall began removing troops on November 23 and by November 24 all had left. Although the strike lingered until December 24, the troops' presence had both intercepted the strikers' effec-

11. Ottumwa Daily Courier, 22 October 1921, 28 October 1921, 1 November 1921, 2 November 1921, 29 October 1921; Des Moines Register, 18 November 1921; Kenneth Ellis and Donald Jones, interviews with ILHOP, 20 October 1978; Alfred Crow, interview.

12. Ottumwa Daily Courier, 15 November 1921, 16 November 1921; Des Moines Register, 16 November 1921. Though the Register says that this was the first use of the state guard since 1913, this is an error. See Kate Rousmaniere, "The Muscatine Button Workers' Strike of 1911-12: An Iowa Community in Conflict," Annals of lowa 46 (Spring 1982), 257-258. 
tiveness and increased the growth of the replacement work force. Circumstances may have doomed the strike from the outset. Strikers received no financial support from the Amalgamated's national headquarters. The strike occurred during winter-and this, combined with the intervention of strikebreakers and state and local authorities on the company's side, spelled defeat for the strike and the union. ${ }^{13}$

After the strike the company treated returning union workers harshly. Alfred Crow recalled that the company "had it in for us young guys, they wanted to break us ... they were very mad." Many demotions occurred; management moved men to the trimming rooms where only low-paid women had worked before the strike. The company retained or eventually rehired many of the scabs, which increased the bitterness between families of loyal union supporters and those who had crossed the picket lines. Moreover, the strike reinforced the firm antiunion stances of T.H. Foster (soon to become president of the company) and Ernest Manns, both of whom would help shape management attitudes toward labor during the next two decades and would, because of their adherence to old-style worker control, keep the company's excursions into New Era welfare capitalism from changing power relationships or instilling cooperative attitudes. ${ }^{14}$

In October 1922, to take advantage of the situation which the lost strike created and to follow the lead of the major packers (including Armour, Swift, Cudahy, and Wilson), Morrell introduced its own employee representation plan: the plant council. At the time, employers were adopting such plans nationwide. Their number had grown from 225 plans covering 500,000 workers in 1919 to 725 affecting over 700,000 workers in 1922. This trend reached a peak in 1926 when over 800 plans covered about $1,500,000$ employees. ${ }^{15}$ Also during the early

13. Ottumwa Daily Courier, 21 November 1921; Des Moines Register, 21 November 1921, 22 November 1921, 23 November 1921, 30 November 1921, 18 November 1921; Cheever, House of Morrell, 189; Alfred Crow, interview.

14. Alfred Crow, interview; Cheever, House of Morrell, 190; Paul Bissell, interview.

15. On company union formation during this period, see U.S. Bureau of Labor Statistics, Characteristics of Company Unions, 1935, Bulletin No. 634 
1920s, Morrell established personnel and employment departments, a foremen's club, and various other financial and social welfare programs. A group life insurance plan would supplement the already existing Mutual Aid Association, and Morrell offered a vacation plan and the Morrell Credit Union. Among the more socially oriented activities established were athletic leagues, Morrell Magazine, company picnics, and the Morrell Male Chorus. Morrell hoped that these programs would forge new ties between employees and the company and thus keep out independent union activity.

Management modeled the plant council on the unicameral Rockefeller (or Colorado) plan which the Colorado Fuel and Iron Company first introduced in October 1915. At Morrell it provided for a monthly meeting between equal numbers, usually eleven each, of plant and management representatives. A chairman and secretary from management conducted the meetings, and employees elected plant representatives in either March or September. Each of the plant's divisions (which were approximately equal in numbers of employees) chose a representative to serve a one-year term. The chairmen would then appoint the elected representatives to serve on one of six standing committees: rules, sanitation, athletics, safety, hours and wages, or grievance. Employees with questions or problems for the plant council were supposed to submit them to their representatives, who would then bring them up at the council meetings. Management could also submit questions and reports. This was "industrial democracy."16

The actions of the plant council, however, could not infringe upon management's right to control company proper-

(Washington, D.C., June 1937), 10, 19, 83, 181. This government survey found that strikes were the greatest relative cause of company union formation between 1920 and 1922. The survey also showed that two-thirds" of the employers who had company unions also conducted separate welfare activities. See Brody, Butcher Workmen, 99-100; Brandes, American Welfare Capitalism, 126-127; Nelson, "Company Union Movement," 338.

16. Brandes, American Welfare Capitalism, 123-125. In 1934, Morrell introduced an employee-only council (without management representation) at the Ottumwa plant to meet NIRA specifications. Hence this description of the council's format applies only to the period from 1922 to 1934 . Since the two functioned in a similar manner with similar powers, however, this study considers both as a single entity from 1922 to 1937 . See the Ottumwa Daily Courier, 16 July 1973. 
ties or to direct the work force through hiring, transferring, or firing. Its actions could not extend beyond recommendations. These, when passed by a two-thirds majority, were to go to the plant superintendent who could either implement them or refer them to the company president, who also could either implement them or refer them back to the council for reconsideration. An employee, moreover, could file a grievance with the plant council only after conferences with his foreman, the superintendent of his department, and the plant superintendent. An employee could consult the employment supervisor at any time, but often such a consultation was unhelpful. Only after the plant council's consideration could employees appeal their grievances to the higher company officials. ${ }^{17}$

Clearly, in the Morrell case, the label "industrial democracy" was a misnomer. Management never intended the council to settle grievances or pass recommendations itself, and it never served as an effective means of labor-management bargaining as Swift's packing plants or the Buckeye Steel Castings Company plant in Columbus, Ohio came close to achieving. As historian Daniel Nelson has argued, the extent of industrial democracy in the many company unions of the period varied greatly. The Morrell case, however, casts doubt on his view that the longer such unions existed the more liable they were to achieve a degree of democracy. This plant showed that one company union could persist without "innovative plant management and ... progressive personnel practices. ${ }^{\prime 18}$

More applicable to the situation at Morrell is Herbert Feis's characterization of the company union meetings at the Cincinnati, Ohio plant of Proctor and Gamble. There, Feis claimed, the topics of discussion were generally "fix a stairway, arrange for train services, stop leaky roofs, carry off fumes, [and]

17. A Handbook for the Employees of John Morrell and Company (Ottumwa, Iowa and Sioux Falls, South Dakota, 1924), 18-21, 23-24, in "Miscellaneous file," box 27, John Morrell and Company Records, Special Collections, University of Iowa Libraries. The government survey on company unions showed that only one-third of those studied handled grievances effectively. See U.S. Bureau of Labor Statistics, Characteristics of Company Unions, 201.

18. Barrett, "Work and Community," 377-378; Brody, Butcher Workmen, 172; Blackford, "Scientific Management," 247-258; Nelson, "Company Union Movement," 336-339. 
arrange a summer outing." At Morrell's the most consistently discussed matter of business was the confirmation of vacations, which the strict rules governing vacation allowances necessitated. In addition, meetings regularly interpreted rules regarding Morrell athletic teams and scheduled athletic events. Topics of discussion such as who would play on the Morrell baseball teams, and the towel distribution system, were often the chief items considered, since addressing issues of larger importance was often futile. ${ }^{19}$

According to the Employee Handbook, wages and hours were legitimate areas for council concern, and on occasion issues relating to them did come before the council. In no case, however, did they change as a result of council action, and in no respect did the council ever serve as a bargaining agent on such matters. Meetings held in March 1927, April 1928, July 1930 , and June 1934 which considered wage readjustments and changes in the plant's work week, all resulted in council recommendations to implement upward adjustments. When management considered the suggestions, it rejected them. Nonetheless, management decreased guaranteed hours and wages in 1931 and 1932, without any kind of council consultation. A major weakness of the Morrell plant council system, then, was management's prerogative to disregard the council's directives. ${ }^{20}$

Another primary weakness of the plant council was its inability to settle employee problems or grievances until after their presentation to the foremen. In various instances where workers complained about the plant environment or mistreatment by foremen, the council refused to consider the grievance unless the complainant had first brought it to the foremen's

19. Feis, Labor Relations, 69-70; Dunn, Company Unions. For the Morrell meetings, see Morrell Magazine, June 1926, 11; February 1927, 11; February $1928,11$.

20. Emiployee Handbook, 18; Morrell Magazine, March 1927, 11; May 1928, 11, 20; August 1930, 11; July 1934, 21; October 1931, 19; March 1933, 24; Kenneth Ellis, interview with ILHOP. Sanford Jacoby has noted that foremen still determined wages throughout the 1920s even in plants where personnel departments existed ("Rise of Internal Labor Markets," 511-512). John Moses, interview with author, 12 September 1982. Jack Moses started work in the smoked meat department in 1926. In the 1940s, he worked in the industrial engineering department and later he became a divisional superintendent for the sausage department. 
attention. In this respect the council reinforced traditional methods of handling grievances and traditional work roles. Under these circumstances the workers could expect very little satisfaction and probably some chastisement for complaining. Virgil Bankson said: "You might as well not tell them you got a problem because they'd do nothing for you. It was a big joke, this plant council." Indeed, Art Bankson laughingly recalled that many of the workers chided the representatives about the "ice cream and cake" served to them at the meetings. Gust Hallgren, a foreman in the curing department during the twenties and thirties and a management representative at some of the meetings, when asked about the council, could only smile and concede that it "didn't work." 21

Initiated at the same time as the plant council were the employment and personnel departments, which together supervised the group life insurance plan, Mutual Aid Association, vacation plan, athletic programs, and events such as the company picnics. These departments, however, did not assume the foremen's and superintendents' traditional power over hiring and firing. Their first director, Nelson G. Rupp, was not a professional personnel specialist of the stature which some New Era companies employed. Morrell had hired him six months earlier as a salesman and had given him his new position because he had a high school coaching background and a short term as personnel director of the DeVilbus Company of Toledo, Ohio. Art Bankson recalled that men seeking jobs usually lined up in front of an employment office (in the general office building) which had a staff of two men and a "lady secretary." These three people "didn't do anything" to select workers. Ernest Manns came out of the building every morning and chose the men he wanted, or, as in Bankson's own case, beef-department superintendent Art Woodman might hire after a personal appeal such as Bankson's brother Virgil made for Art. Art Bankson also remembered that, on occasion, foremen and superintendents acted as recruiters, and even

21. Morrell Magazine, July 1927, 11; June 1928, 11; July 1928, 11; January 1929, 24; Kenneth Ellis and Donald Jones, interview with ILHOP; Elmer Cline, interview with ILHOP, 25 September 1981; Virgil Bankson, interview with ILHOP; Art Bankson, interview; Gust R. Hallgren, interview with author, 16 April 1983. 
called discharged or retired butchers on the telephone to offer them temporary employment. Morrell was apparently among those companies that Daniel Nelson described as having low degrees of commitment to personnel work, and it was clearly among those that Sanford Jacoby has identified as leaving the traditional powers of foremen and factory superintendents largely intact. ${ }^{22}$

The power over transfers, clearly stipulated as a managerial prerogative in the Employee Handbook, also remained with foremen and superintendents. They continued to exercise it in an arbitrary fashion with little regard for either personnel science or workers' feelings about seniority and job rights. Alfred Crow, Donald Jones, and Virgil Bankson recalled that workers' had to do whatever the bosses told them, especially during the Depression, when management prodded them with the threat that "three or four hundred men ... [are] out in line ready to take your place." Virgil Bankson felt arbitrarily switched from one department to another and expressed his resentment by walking out on his job when the company promoted ahead of him a man who had worked there less time than Bankson. "I hoped to get a job driving a city delivery truck," he reminisced, "but they pulled another guy out of a department and transferred him to do it." The foreman could and did play favorites. His influence in discharging workers, although the implementation of the plant council curtailed it somewhat, remained more important than anyone else's. Paul Bissell said, "if a foreman didn't like the color of your eyes you'd be out." Beyond these powers, foremen could also engage in petty harassment. Workers resented unreasonable enforcement of the system of tickets and tags which regulated restroom use and the arbitrary measures taken to prevent "cheating" the company out of working time..$^{23}$

22. Morrell Magazine, January 1927, 9; May 1927, 6; Art Bankson, interview; Nelson, "Company Union Movement," 343-344; Jacoby, "Rise of Internal Labor Markets," 508. For sources which elaborate the inroads some personnel departments made into the foremen's traditional realms, see Bernstein, Lean Years, 177; Green, World of the Worker, 102-110; and Daniel Nelson, Managers and Workers: Origins of the New Factory System in the United States, 1880-1920 (Madison, 1975), 48.

23. Employee Handbook, 23-24, 41-42; Virgil Bankson, interview with ILHOP; Alfred Crow, interview; Frances Calhoon, Donald Jones and Virgil Bankson, interview with Local P-1, Amalgamated Meatcutters and Butcher 
Morrell also established, in March 1925, a foremen's club, which was one way the company gave the old foremen system a modern and progressive veneer. It became an agency for fostering comradeship and "right thinking" among foremen and for instructing them in techniques to gain greater efficiency and productivity from the work force. In addition, the club seemed to be a substitute for a centralized planning or engineering department. The Ottumwa plant did not initiate other more "scientific" management schemes, such as time studies, until the 1940s when it did establish an industrial engineering department. Under the club's sponsorship, some men attended courses on foremanship which the Iowa State College Engineering Extension Service offered. At one of the earliest foremen's club meetings, Ernest Manns hypocritically recommended that foremen be "diplomats who get results without the bluster and profanity of other days." These efforts did not change what Sanford Jacoby has called the "drive" methods of foremanship, since foremen continued to rely upon toughness and fear to ensure workers' proper behavior. Many foremen had worked their ways up through the ranks where profanity and intimidation were the accepted methods of ensuring worker effectiveness. Not surprisingly, such men had little sympathy with "scientific" personnel work that challenged both practical wisdom and the validity of their careers. Traditional foremanship caused many of Morrell's smoldering dissatisfactions which surfaced in the unionization drive of the 1930 s. ${ }^{24}$

Workmen of North America (AMCBW), Iowa State Historical Department, Iowa City; Violet Bohaty, interview with ILHOP, 15 September 1981. Bohaty also commented that arbitrary transfers still occurred in 1936 when she started work in the sausage department. Gust R. Hallgren, interview; Paul Bissell, interview; Elmer Cline, interview; George Gail, interview with author, 13 January 1983. A beef-department employee who began in 1934, Gail recalled that one could only use the restroom once every five hours for only five minutes at a time. He added that it often took five minutes simply to reach a restroom.

24. Jacoby, "The Rise of Internal Labor Markets," 56-68, 508-509, 556-557; Cheever, House of Morrell, 197; Morrell Magazine, April 1925, 6, 21; August 1925, 6; and for Ernest Manns's remarks see June 1925, 3; John Moses, interview; Gilbert Baker, interview with author, 4 August 1982. Baker started work in the trimming room in 1928 and during the 1940s and 1950s was a draftsman for the industrial engineering department. Indications of the types of careers found among the foremen and superintendents appear in the 
Morrell's management also implemented welfare capitalist measures in the form of new or expanded benefit programs, including a revised version of the old Mutual Aid Association. This, prior to 1925, had deducted ten cents from each participating employee's weekly paycheck and used the money to provide weekly disability benefits of five dollars or less. Under the new plan, employees earning more than $321 / 2$ cents per hour paid fifteen cents per week while those earning less paid ten cents. Such proceeds made possible a maximum disability benefit of $\$ 1.50$ per day for those in the first category and $\$ 1.00$ per day for those in the second (in each case the employee could receive payments for no more than thirteen weeks). Also available was a death benefit provision applicable to those who had at least five years of service. It provided payments of $\$ 500$ for those in the higher-earning bracket and $\$ 333.33$ for those in the lower one. The amounts paid were not inconsequential and the program was probably important for the one-half to two-thirds of the work force that participated. The employees themselves, however, were still the only source of funding; the company's role was purely administrative, which may account for low employee participation in the program. ${ }^{25}$

The company initiated and funded the group life insurance plan in 1924 and made it available to all employees who had been on the payroll for at least one year. Its minimum death benefit was five hundred dollars after the first year, which would increase by one-hundred-dollar increments for each additional year at Morrell to a top figure of two thousand dollars after fifteen years. In addition, the insurance plan included a total disability clause under which the worker could also receive the full amount accrued. The company clearly intended the plan to induce employees to stay, and together with the Mutual Aid Association fund, it provided family assistance when Morrell employees died or became permanently

sketches of John Denefe, Lyle Mosher, and Oscar Johnson in Morrell Magazine, November 1926, 7; May 1926, 7; and November 1926, 16, respectively.

25. Morrell Magazine,. December 1925, 3. The figures of "one-half to two-thirds of the work force" are a rough average of those Morrell Magazine gave from 1926 to 1933 . 
disabled, injured, or ill. The plant had no pension plan until January $1941 .{ }^{26}$

Judging by the amount of space allotted to it in Morrell Magazine and the amount of time devoted to it in plant council meetings, the vacation plan was the most celebrated of the new Morrell programs. Management announced it on September 4, 1923, and made it apply to all employees who had been working since January 1 of that year. Like the life insurance plan, management clearly directed it toward reducing labor turnover rates. "Employees who can be depended upon to be in their places," Morrell Magazine announced, "are of much more value to John Morrell and Co., and so are given a week's vacation with pay for each year of uninterrupted service." The company based pay for this week of vacation on a usual forty-eight-hour work week for the hourly-wage employees or, for piece workers, on the average weekly earnings for the four weeks immediately preceding the vacation. Employees had to take their vacations within twelve months of earning them and at a time convenient for the company. Until August 1928 it was impossible for an employee to keep working and take an added week's pay in lieu of vacation. A matter of great concern about the vacation plan was the amount of time that an employee could miss without ruining an uninterrupted service record. The rules limited this to no more than six hours during the year, which meant that an employee could not miss a full working day. ${ }^{27}$

Needless to say, most employees had difficulty meeting these requirements. In 1925, for example, only 428 of a total of 2,485 employees earned a week of vacation, and in the plan's first three years only thirty-four employees earned three consecutive vacations. Subsequently, twenty-eight received vaca-

26. Employee Handbook, 46-47; Morrell Magazine, August 1924, 4; July 1925, 5; January 1941, 2.

27. Morrell Magazine, June 1925, 10; September 1928, 11; Plant Council Bulletin, 1 October 1923, in "Miscellaneous file," box 27, John Morrell and Company Records, Special Collections, University of Iowa Libraries. Before July 1926, employees were allowed eight instead of six hours of uninterrupted service. See Morrell Magazine, July 1926, 6; December 1924, 9; February 1926, 19; January 1928, 21; May 1931, 11. Not until April 1931 did the company relax this rule somewhat for employees with twenty-five years or more of service. It allowed them to miss three additional days. 
tions for four consecutive years, eighteen for five consecutive years, eleven for six consecutive years, nine for seven consecutive years, six for eight years, five for ten years, and four for twelve years. One of these remaining four, Joseph Hanrahan, had been the plant tour guide. As these figures make apparent, the vacation plan was a benefit that reached only a small number of workers.

Another, much more successful financial program came somewhat late in Morrell's years of welfare capitalism. Initiated in 1931, the Morrell Credit Union had 496 members by 1934. In 1935 its membership almost doubled (987), and by the end of the decade 1,344 Morrell employees had joined it. During the Depression, credit may have held more attraction than even vacations did. ${ }^{28}$

In addition to the Mutual Aid Association, group life insurance plan, vacation plan, and credit union, John Morrell and Company introduced four social welfare programs. It sponsored athletic teams which were particularly popular, and as early as 1922 employees could participate in baseball and basketball leagues. The company also published its own monthly organ, Morrell Magazine, beginning in July 1924 and mailed it free to all workers. It provided some entertaining and educational material on topics such as American cities and vacation spots but primarily attempted to instill cooperative and industrious work habits. In 1925, Morrell revived the company picnic of the 1880s. Though enthusiastic at first, employees' interest declined when management scheduled the picnics on working days and did not reimburse employees for the missed day as it had done during the late nineteenth century. In 1928, 1929 , and 1930 there were no picnics, and when held again in 1931, they occurred after working hours. Finally, the Morrell Male Chorus formed in October 1930, and management supported it as part of public relations. The chorus made numerous appearances in and out of the state. Chorus members

28. Morrell Magazine, December 1925, 5; March 1933, 24. The 2,485 figure includes employees who worked part-time during the year. The other figures are from Morrell Magazine, September 1926, 11; February 1927, 24; February 1928, 6; February 1929, 8; January 1930, 7; January 1931, 6; January 1933, 5; and January .1935, 6. On the credit union see Morrell Magazine, February 1934, 3; February 1936, 6; and February 1939, 4. 
received time off with pay and meal money for concerts. Even so, the chorus drew its members chiefly from management and consequently had limited employee participation. ${ }^{29}$

MORRELl undoubtedly hoped that these welfare programs would help unite the plant into one big "family." In all probability management believed that it was meeting employee concerns. Yet the plant council was unable to function as an equal partner or bargainer with management, and traditional foremanship continued. The reform attempted in these areas did little to create the mutual respect and sense of fairness that might have fostered stable industrial relations. The company's financial and social welfare activities were marginal in effect; they did not touch the most fundamental concerns of aggrieved workers. Essentially, workers wanted to increase their pay, secure more regular employment, better their working conditions, and, most important, increase their control in plant affairs.

Regardless of the company's presumably good intentions, during the twenties and thirties Morrell plant employees had the reputation of being the "poorest people in town." Clarence Orman, who had started work in the smoked meat department in 1926, remembered that, with the onset of the Depression, "guys delivering groceries" made more money than he did. Virgil Bankson recalled that during the same period many people, including Bankson and his wife, lived in one-room shacks. Many employees had gone to work as soon as they finished grade school, and had taken jobs that, for the most part, only required physical strength and willingness to work hard. ${ }^{30}$

In part, workers suffered from the wage cuts of 1931 and 1932, which fell especially hard on plant employees. After the cuts, for example, Virgil Bankson was making only $\$ 10.40$ per week while Earl Paxson, a department sales manager, was still

29. Morrell Magazine, July 1924, 3; May 1930, 10; August 1928, 11; August 1929, 11; May 1931, 11; Agency Tribune, 1886; Alfred Crow, interview; John Moses, interview. Jack Moses later became a director of the chorus.

30. Elmer Cline, interview; Clarence Orman to Wilson J. Warren, 19 July 1982; Clarence Orman, interview with author, 25 September 1982; Virgil Bankson, interview with ILHOP. 
earning $\$ 72$ per week (down from $\$ 80$ ). Wage cuts were not the whole story, however. Even in the 1920s many of the plant's jobs paid very low wages; indeed, apparently few workers then earned even forty cents per hour, which had been the minimum wage for unskilled laborers before the 1921 strike. In 1923, for example, Kenneth Ellis hired on as an "off-bearer" at twenty cents per hour; two years later Virgil Bankson made thirty-two cents an hour in the smoked meat department; and in 1929 Gilbert Baker made thirty-five cents in the same department. Ira Bartholow, who started at the plant during World War I, recalled that he received only $371 / 2$ cents per hour in 1924 for the arduous task of "beef lugging"-hooking sides of beef, which sometimes weighed close to a quarter of a ton, on racks in the meat cooler. Still lower were the wages paid to male teenagers, some of whom did the same work as adults. Morrell's management did not adhere to the "doctrine of high wages" that for some companies, if historian David Brody is correct, was the essential element of success. Brody's argument that welfare capitalism failed primarily because of the Depression's decline in workers' wages does not wholly explain why welfare capitalism failed at Morrell. The company did not pay high wages to its plant employees before the Depression. ${ }^{31}$

Many employees' difficulties during this period resulted from the seasonal nature of the packing business. Employment at the plant was closely tied to peak hog-killing seasons, and most activity occurred from early September to January. Most of the kill and cut department employees faced lay-offs in the spring and summer without any kind of income except possible part-time jobs helping farmers with planting and har-

31. Virgil Bankson, interview with ILHOP; Kenneth Ellis, interview with ILHOP; Gilbert Baker, interview; Ira Bartholow, interview with ILHOP, 19 October 1978; Earl Paxson, interview with author, 27 June 1982. Paxson began at the Morrell plant in Ottumwa in 1909 as a secretary for T. H. Foster, a position he says he received by exaggerating his secretarial abilities. On teenage workers, see Warren, "Workers and Labor Organizing," 10, 18. Since the Morrell plant's opening in 1877, young boys typically worked there, which was also common in other packing plants. See also George Gail, interview. On the "doctrine of high wages" see Brody, "Rise and Decline of Welfare Capitalism," 61-66, 71-78. For a position downplaying the doctrine's use, see Bernstein, Lean Years, 179-180. Brody cites the average wage of an industrial worker in 1922 as forty-eight cents per hour, while in 1929 it was fifty-six cents per hour (62). 
vests. Even during peak seasons, as Alfred Crow pointed out, kill-department employees often had to compete with "boomer" butchers who traveled from packing house to packing house "chasing the best jobs." 32

Although most jobs in a packing plant did not take long to learn, some of the operations in the beef-kill and hog-kill departments required training and some degree of skill. Their practitioners took great pride in their work. The floorsmen in the beef-kill department; for example, had to skin a specified number of cattle per hour. In practice they were the leaders of the beef kill, since their efforts determined the pace of the other operations in the department. To a certain extent, the kill departments also set the pace for the entire plant's operations. Therefore the people in these departments had to bear the full brunt of the foremen's rantings, ravings, and whistlings to keep up the pace of their work. ${ }^{33}$

The work environment in the kill rooms made the workers acutely aware of company power as well. Don Jones recalled that pleas to install fans in the hog kill, for example, went unheeded, although the company was willing to sell sponges to the men as an alternative. Workers had to buy all of their knives, tools, and work clothes from the company, too. In 1932, the plant council dismissed an appeal to change this rule; rather than "take up the time of the council," it referred the request to the foreman of the department. Workers in the kill departments also faced the danger of jobs such as "shackling" (attaching a chain to a hog's leg in order to hoist it onto the conveyor) and "sticking" (cutting a hog's throat so the blood could drain out while it hung suspended from the conveyor). To perform such tasks, a worker often had to literally battle the animals until they were dead, while risking accidental stabbing. Yet management took little of this danger into account as it pressured workers for speed and productivity. For men of skill and pride such situations offered clear evidence

32. Paul Bissell, interview; Alfred Crow, interview; Elmer Cline, interview; Gilbert Baker, interview. The "boomer" butcher phenomenon seems to have declined by the end of the 1920s as workers became less transient.

33. Virgil Bankson, interview with ILHOP; Donald Jones, interview with Local P-1; Elmer Cline, interview. 
of company power and worker helplessness. For kill-department employees especially, the improvement of working conditions required actions that would divest them from the company's hegemony. ${ }^{34}$

The welfare capitalist measures which John Morrell and Company sponsored from 1922 to 1937 had failed to meet the needs of its employees, especially those in the kill departments. Basically, the workers wanted some respect and influence in decisions which affected plant affairs. This is not what they received. The plant council could not deal with grievances directly, nor could it act as a collective bargaining agent for the plant employees. It could only consider minor aspects of the workers' welfare. The personnel and employment departments did not deprive foremen of their traditional power, and the foremen's club neither modernized the exercise of foremanship nor ended its abuses. Indeed, Morrell apparently never intended to make such changes. While some of the other programs were beneficial, the group life insurance plan and the Morrell Credit Union for example, they were generally too limited or too peripheral to have much impact on the workers' situation. It is not surprising, then, that the result of the welfare-capitalist period was the workers' rejection of management domination. The workers wanted greater pay, better working conditions, more control over their jobs, a seniority system, job rights, and restrictions on indiscriminate transfers. Ultimately, such issues sparked Virgil and Art Bankson, Donald Jones, Paul Bissell, and others in the beef-kill and hog-kill departments to seek an organization independent of company control or influence. As Virgil Bankson recalled, the men's basic need expressed by establishing a union was "to have a voice in what you're doing." After their organization in the mid-1930s their efforts finally succeeded in 1937 by making the Packinghouse Workers' Organizing Committee of the Committee for Industrial Organization (CIO) the plant employees' bargaining representative. ${ }^{35}$

34. Donald Jones, interviews with ILHOP and Local P-1; Morrell Magazine, August 1932, 21. Larry D. Englemann, in "'We Were the Poor People'-The Hormel Strike of 1933," Labor History 15 (Fall 1974), 491, notes kill-department employees' role as leaders of 1930s union drives in meatpacking plants. $1937,2$.

35. Virgil Bankson, interview with author; Morrell Magazine, November 
Copyright of Annals of Iowa is the property of State of Iowa, by \& through the State Historical Society of Iowa and its content may not be copied or emailed to multiple sites or posted to a listserv without the copyright holder's express written permission. However, users may print, download, or email articles for individual use. 